\title{
DETERMINAN DAYA SAING SEKTOR MANUFAKTUR UNGGULAN MENUJU PROGRAM MAKING INDONESIA 4.0
}

\author{
(Determinants of Competitiveness of the Leading Manufacturing Sector for Making \\ Indonesia 4.0 Program)
}

\author{
Muhammad Mubin Mubyarto1, Gama Putra Danu Sohibien² \\ Politeknik Statistika STIS ${ }^{1}$ \\ Politkenik Statistika STIS 2 \\ Jalan Otto Iskandardinata 64C, Jakarta Timur \\ E-mail: muhammadmubin379@gmail.com
}

\begin{abstract}
ABSTRAK
Pemerintah merancang sebuah peta jalan Making Indonesia 4.0 dalam menghadapi persaingan tinggi di era revolusi industri 4.0, dimana penerapan teknologi digital sangat tinggi. Terdapat lima sektor manufaktur yang menjadi fokus pengembangan yaitu industri makanan dan minuman, industri tekstil dan pakaian jadi, industri kimia, industri elektronik, dan industri otomotif. Penelitian ini bertujuan untuk mengetahui gambaran daya saing sektor manufaktur unggulan di Indonesia, posisi daya saing sektor manufaktur unggulan di ASEAN, serta menganalisis variabel yang memengaruhi daya saing sektor manufaktur unggulan. Metode yang digunakan yaitu Revealed Comparative Advantage (RCA) dan regresi data panel. Hasil penelitian menunjukkan secara rata-rata pada tahun 2000 hingga 2015, sektor yang memiliki daya saing adalah industri makanan dan minuman, yang menempati peringkat ketiga diantara negara ASEAN lainnya, serta industri tekstil dan pakaian jadi di peringkat keempat. Sedangkan industri kimia, industri elektronik, dan industri otomotif tidak memiliki daya saing. Produktivitas tenaga kerja, Foreign Direct Investment, dan jumlah perusahaan berpengaruh signifikan positif, sedangkan nilai tukar berpengaruh signifikan negatif terhadap daya saing sektor manufaktur unggulan.
\end{abstract}

Kata kunci: daya saing, Revealed Comparative Advantage (RCA), regresi data panel, sektor manufaktur unggulan

\section{ABSTRACT}

The government designed Making Indonesia 4.0 for facing the high competitiveness in 4.0 industrial revolution, where the application of digital technology was very high. There are five manufacturing sectors that focused on development, namely food and beverage industry, textile and apparel industry, chemical industry, electronics industry, and automotive industry. This study aims to describe the competitiveness of the leading manufacturing sectors in Indonesia, the competitive position of the leading manufacturing sectors in ASEAN, and analyze variables that affect the competitiveness of the leading manufacturing sectors. The method are Revealed Comparative Advantage (RCA) and panel data regression. The results showed that, on average, from 2000 to 2015, the competitiveness sector was the food and beverage industry ranked third in other ASEAN countries, and the textile and apparel industry ranked fourth. While the chemical industry, electronic industry, and the automotive industry have no competitiveness. Labor productivity, Foreign Direct Investment, and the number of companies have a significant positive effect, while the exchange rate has a significant negative effect on the competitiveness of the leading manufacturing sector.

Keywords: competitiveness, leading manufacturing sector, panel data regression, Revealed Comparative Advantage (RCA)

\section{PENDAHULUAN}

Era revolusi industri gelombang ke empat atau disebut Revolusi Industri 4.0 telah tiba dan tidak dapat dihindari. Revolusi Industri 4.0 ini merupakan suatu proses industri yang terhubung secara digital yang mencakup berbagai jenis teknologi termasuk artificial intelligence (AI), e-commerce, big 
data, fintech, shared economies, hingga penggunaan robot yang diyakini mampu meningkatkan produktivitas. Revolusi industri 4.0 ini dapat menjadi masalah jika industri tidak mampu menyesuaikan diri dengan perkembangan teknologi yang tinggi. Kemudian Kementerian Perindustrian Indonesia meluncurkan Making Indonesia 4.0 sebagai sebuah roadmap atau peta jalan mengenai strategi Indonesia dalam memasuki era Industri 4.0. Making Indonesia 4.0 akan fokus pada lima sektor manufaktur, yaitu: (1) industri makanan dan minuman, (2) tekstil dan pakaian, (3) otomotif, (4) kimia, serta (5) elektronik. Kelima sektor industri ini merupakan tulang punggung yang diharapkan dapat menjadi pionir implementasi industri 4.0 dan memberikan kontribusi nyata pada perekonomian Indonesia.

Kelima sektor unggulan tersebut memiliki tujuan tersendiri yang hendak dicapai. Pertama, industri makan minum ditargetkan menjadi yang terkuat di ASEAN. Kedua, menjadikan industri tekstil dan pakaian sebagai produsen functional clothing terkemuka. Ketiga, menjadi produsen mobil terbesar di ASEAN dan basis produksi internalcombustion engine (ICE) maupun electrified vehicle (EV). Keempat, memperluas kapasitas dan membangun kemampuan sektor kimia menjadi net eksportir dan produsen bahan kimia spesialis. Kelima, mengembangkan kemampuan industri domestik sektor elektronik.

Dalam rangka mencapai tujuan program Making Indonesia 4.0, pemerintah perlu membangun industri yang berdaya saing. Daya saing merupakan salah satu kriteria yang menentukan keberhasilan suatu negara di dalam perdagangan internasional. Dalam era perdagangan bebas saat ini, daya saing sebuah produk menjadi syarat mutlak yang harus dipenuhi agar produk tersebut dapat bertahan di pasar internasional (Karlinda, 2012). Dengan memiliki daya saing, dapat memacu suatu negara dalam meningkatkan perekonomian secara berkelanjutan. Sehingga negara tersebut dapat memperkuat diri dalam pasar internasional, meningkatkan nilai ekspor sehingga dapat memberikan dampak positif terhadap PDB yang selanjutnya dapat meningkatkan kesejahteraan masyarakat. Raimanu (2016) menyebutkan bahwa daya saing sebuah negara dianggap sebagai salah satu sumber dari ketahanan suatu negara dalam menghadapi tantangan dalam membangun peradaban bangsa. Sebab peradaban hanya dapat dibangun melalui kekuatan ekonomi, politik, dan budaya yang unggul. Dengan daya saing tinggi, negara dapat menjaga pertumbuhan ekonominya dan mulai membangun kehidupan negara yang teratur dan saat itu pembangunan peradaban dimulai. Pembangunan peradaban tidak dapat dilakukan tanpa adanya kekuatan ekonomi. Dan kekuatan ekonomi tidak dapat ditegakkan tanpa adanya daya saing. Dengan demikian, daya saing menjadi sangat penting untuk keberlanjutan perekonomian dan peradaban suatu bangsa.

Berdasarkan data Badan Pusat Statistik (BPS), sektor industri menduduki peringkat tertinggi dalam kontribusinya terhadap PDB dan nilai ekspor. Persentase kontribusi PDB sektor industri pada tahun 2015 sebesar 20,99 persen, disusul sektor pertanian 13,49 persen, dan sektor perdagangan besar 13,30 persen. Persentase nilai ekspor sektor industri tahun 2015 sebesar 72,26 persen, kemudian sektor penggalian 12,91 persen, dan pertanian 2,48 persen. Pada kelima sektor manufaktur yang dipilih dalam program Making Indonesia 4.0 sendiri memiliki kontribusi tertinggi terhadap PDB industri dengan persentase 26,75 persen pada sektor makan minum, 5,76 persen pada sektor tekstil dan pakaian, 8,67 persen pada sektor kimia, 9,37 persen pada sektor elektronik, dan 9,12 persen pada sektor otomotif.

Namun, tingginya nilai kontribusi sektor industri terhadap PDB dan ekspor tidak diikuti dengan pertumbuhan yang baik. Pada tahun 2011 pertumbuhan sektor industri sebesar 6,26 kemudian menurun menjadi 4,33 pada tahun 2015. Nilai ekspor kelima sektor manufaktur unggulan tersebut juga mengalami penurunan dalam beberapa tahun terakhir. Pada tahun 2011 nilai ekspor sektor industri makanan dan minuman sebesar 27,5 miliar USD menjadi 25,9 miliar USD pada tahun 2015. Kemudian sektor industri tekstil dan pakaian jadi dari 11,9 miliar USD pada tahun 2011 menjadi 11,3 miliar USD pada 2015. Sektor industri kimia dari 13,2 miliar USD pada 2011 menjadi 10,4 miliar USD pada 2015. Selanjutnya sektor industri elektronik dari 12,7 miliar USD pada 2011 menjadi 9,9 miliar USD pada 2015. Hanya sektor industri otomotif yang terjadi kenaikan dari 5,1 miliar USD pada 2011 menjadi 6,39 miliar USD pada 2016.

Berdasarkan Global Competitiveness Report tahun 2015, daya saing Indonesia saat ini berada pada urutan ke-37 dunia dari 140 negara. Sedangkan di kawasan ASEAN sendiri, daya saing Indonesia berada di peringkat empat, masih tertinggal dari Singapura di urutan pertama, Malaysia 
di urutan kedua, dan Thailand di urutan ketiga. Berdasarkan nilai ekspor manufakturnya, pada tahun 2015 Indonesia berada di urutan ke lima di ASEAN dengan nilai ekspor 74,4 miliar USD di bawah Singapura di urutan pertama dengan nilai ekspor 323,5 miliar USD, Thailand dengan nilai ekspor 201,2 miliar USD, Malaysia dengan nilai ekspor sebesar 156,8 miliar USD, dan Vietnam dengan ekspor sebesar 138,72 miliar USD.

Dari uraian di atas menunjukkan adanya masalah peningkatan ekspor manufaktur unggulan dalam upaya meningkatkan daya saing sektor manufaktur unggulan Indonesia untuk dapat bersaing di era revolusi industri 4.0. Kemampuan bersaing sektor manufaktur yang dipilih dalam program Making Indonesia 4.0 perlu dipahami dengan melakukan komparasi terhadap sektor manufaktur sejenis dari negara-negara pesaing. Kemudian dapat dilihat subsektor manufaktur mana yang lebih bersaing atau kurang bersaing daripada sektor manufaktur negara pesaingnya, dalam penelitian ini adalah negara-negara ASEAN, sesuai tujuan dari program Making Indonesia 4.0. Sehingga dalam penelitian ini tujuan yang akan dicapai yaitu mengetahui gambaran daya saing sektor manufaktur unggulan Indonesia dan posisi daya saing sektor manufaktur unggulan di ASEAN, serta mengetahui variabel-variabel apa saja yang memengaruhi daya saing sektor manufaktur unggulan tersebut.

Penelitian serupa pernah dilakukan sebelumnya. Isventina (2015) dalam penelitiannya tentang Analisis Daya Saing Sektor Industri Prioritas Indonesia dalam Menghadapi Pasar ASEAN menggunakan analisis data panel dengan data sekunder dari tahun 2001 sampai dengan 2013 dan cross section berupa 8 (delapan) sub sektor industri prioritas Indonesia. Hasil penelitian menunjukkan lima dari delapan sektor industri prioritas Indonesia memiliki nilai Revealed Comparative Advantage (RCA) rata-rata di atas satu, yang meliputi industri Makanan dan Minuman, industri Tekstil, industri Pakaian Jadi, industri Kulit dan Barang dari Kulit, serta industri Logam Dasar. Kemudian, faktor-faktor yang mempengaruhi daya saing sektor industri prioritas Indonesia adalah harga ekspor, nilai tukar riil Rupiah terhadap Dollar Amerika Serikat dan produktivitas.

Penelitian lainnya dilakukan oleh Bulduk (2011) dalam penelitiannya Determinants of Comparative Advantage in the ICT Goods Market: A Cross Country Analysis. Penelitian dilakukan dengan metode regresi data panel dengan cross section 22 negara dan time series dari tahun 1996 sampai 2009. Hasil penelitian menunjukkan bahwa variabel yang berpengaruh signifikan terhadap daya saing barang ICT adalah jumlah tenaga ahli, produktivitas tenaga kerja, dan pengeluaran Research and Development (R\&D). Sedangkan variabel Foreign Direct Investment (FDI) berpengaruh positif terhadap daya saing barang ICT namun tidak signifikan.

\section{METODE}

\section{Landasan Teori}

Tambunan (2003) menyatakan daya saing merupakan kemampuan suatu komoditi untuk memasuki dan bertahan dalam pasar luar negeri yang diukur dari keunggulan komparatif dan keunggulan kompetitifnya. Suatu negara akan berusaha untuk meningkatkan daya saing produk, barang dan jasa agar dapat masuk dan mempertahankan produk, barang dan jasa negara tersebut di pasar internasional. Terdapat beberapa teori yang menjelaskan daya saing, diantaranya:

1. Teori Keunggulan Komparatif

Teori ini dikemukakan oleh David Ricardo. Ricardo menyatakan bahwa perdagangan internasional terjadi bila ada perbedaan keunggulan komparatif antarnegara. Ketika suatu negara dibandingkan dengan negara lain, meskipun negara tersebut tidak memiliki keunggulan absolut dalam memproduksi dua jenis komoditi, namun masih terdapat dasar untuk melakukan perdagangan yang menguntungkan asalkan terciptanya spesialisasi produksi atas komoditi tertentu yang merupakan keunggulan komparatif negara tersebut.

\section{Teori Modern Heckscher-Ohlin}

Teori ini merupakan kelanjutan teori Ricardo. Teori ini menjelaskan alasan utama perdagangan internasional adalah perbedaan relatif faktor pemberian alam (faktor endowment) dan harga faktor produksi antarnegara. Faktor pemberian alam atau faktor endowment yang dimaksud adalah faktor tanah, manusia, dan modal. Negara-negara yang mempunyai faktor produksi yang relatif lebih banyak atau murah akan melakukan spesialisasi dan mengekspor barang yang dihasilkannya, 
sedangkan negara yang mempunyai faktor produksi relatif lebih sedikit atau mahal akan mengimpor barang tertentu.

3. Teori Keunggulan Kompetitif

Teori ini diperkenalkan oleh Michael Porter. Keunggulan kompetitif adalah keunggulan yang dimiliki oleh suatu negara untuk dapat bersaing di pasar internasional. Ada empat faktor penentu dan dua faktor pendukung dalam teori keunggulan kompetitif. Empat faktor utama yang menentukan daya saing suatu komoditi adalah faktor kondisi, faktor permintaan, faktor industri pendukung, serta faktor strategi, struktur, dan persaingan. Ada dua faktor pendukung yaitu faktor kesempatan dan faktor pemerintahan. Secara bersama-sama faktor ini membentuk sistem dalam peningkatan keunggulan daya saing yang kemudian disebut Porters Diamond's Theory.

Salah satu indikator yang dapat digunakan untuk mengukur daya saing adalah Revealed Comparative Advantage (RCA). Konsep RCA ini pertama kali diperkenalkan oleh Ballasa pada tahun 1965, yang menganggap bahwa keunggulan komparatif suatu negara direfleksikan atau terungkap dalam ekspornya. Nilai RCA menunjukkan keunggulan komparatif atau daya saing dari suatu negara pada suatu komoditas terhadap dunia. Kinerja ekspor produk dari suatu negara diukur dengan menghitung pangsa nilai ekspor suatu produk terhadap total ekspor suatu negara dibandingkan dengan pangsa nilai produk tersebut dalam perdagangan dunia (Tambunan, 2001). Adapun rumus matematis RCA adalah sebagai berikut:

$$
R C A=\frac{\left(X_{i j} / X_{j}\right)}{\left(X_{i w} / X_{w}\right)}
$$

Keterangan:

$X_{i j} \quad$ : Nilai ekspor komoditas $\mathrm{j}$ dari negara $\mathrm{i}$

$X_{j} \quad$ : Nilai ekspor total produk (komoditas j dan lainnya) negara i

$X_{i w} \quad$ : Nilai ekspor komoditas j di dunia

$X_{w} \quad$ : Nilai ekspor total dunia

Dari nilai RCA dapat diketahui bagaimana daya saing suatu produk apakah daya saingnya rendah atau tinggi. Tambunan (2001) menyatakan bahwa nilai RCA lebih dari satu berarti negara tersebut memiliki keunggulan komparatif untuk suatu komoditas lebih besar dari rata-rata dunia. Sebaliknya jika nilai RCA lebih kecil daripada satu berarti negara keunggulan komparatif negara tersebut lebih kecil dari rata-rata dunia. Jika semakin tinggi nilai RCA, berarti daya saingnya semakin tinggi, dan sebaliknya.

\section{Metode Pengumpulan Data}

Data yang digunakan dalam penelitian ini merupakan data sekunder berupa data time series dari tahun 2000 sampai 2015 dan data cross section lima sektor manufaktur unggulan Making Indonesia 4.0 yang diperoleh dari berbagai sumber. Variabel RCA dihitung dengan membandingkan proporsi ekspor sektor manufaktur unggulan Indonesia dengan dunia, nilai ekspor bersumber dari World Integrated Trade Solution (WITS). Variabel produktivitas tenaga kerja dan jumlah perusahaan bersumber dari Badan Pusat Statistik. Variabel nilai tukar bersumber dari Bank Indonesia. Variabel Foreign Direct Investment (FDI) bersumber dari Badan Koordinasi Penanaman Modal Indonesia.

\section{Metode Analisis}

Analisis dalam penelitian ini menggunakan analisis deskriptif dan analisis inferensia. Analisis deskriptif menggunakan RCA dan grafik. Analisis inferensia menggunakan regresi data panel untuk mengetahui variabel-variabel yang memengaruhi daya saing sektor manufaktur unggulan. Berikut adalah tahapan-tahapan dalam melakukan analisis regresi data panel:

1. Pembentukan model regresi data panel

Untuk menganalisis pengaruh produktivitas tenaga kerja, FDI, dan nilai tukar terhadap daya saing sektor manufaktur unggulan Indonesia dapat dispesifikasikan dalam model regresi data panel antara lain Common Effects Model (CEM), Fixed Effects Model (FEM), dan Random Effects Model (REM).

Persamaan CEM dapat dituliskan sebagai berikut:

$$
R C A_{i t}=\alpha+\beta_{1} P R O D_{i t}+\beta_{2} F D I_{i t}+\beta_{3} K U R S_{t}+\beta_{4} J P_{i t}+u_{i t}
$$


Persamaan FEM dapat dituliskan sebagai berikut:

$$
R C A_{i t}=\left(\alpha+\mu_{i}\right)+\beta_{1} P R O D_{i t}+\beta_{2} F D I_{i t}+\beta_{3} K U R S_{t}+\beta_{4} J P_{i t}+v_{i t}
$$

Persamaan REM dapat dituliskan sebagai berikut :

$$
R C A_{i t}=\alpha+\beta_{1} P R O D_{i t}+\beta_{2} F D I_{i t}+\beta_{3} K U R S_{t}+\beta_{4} J P_{i t}+\left(\mu_{i}+v_{i t}\right)
$$

Keterangan:

i : $1,2, \ldots, 5$ (sektor manufaktur unggulan)

$\mathrm{t}: 1,2, \ldots, 16$ (tahun 2000 sampai 2015)

$R C A_{i t}$ : daya saing sektor i peridode ke-t

$P R O D_{i t}$ : produktivitas tenaga kerja subsektor i peridode ke-t (miliar rupiah)

$F D I_{i t}$ : FDI subsektor i tahun t (miliar USD)

$K U R S_{t}$ : nilai tukar periode ke-t (Rupiah/USD)

$J P_{i t}$ : jumlah perusahaan subsektor i periode ke-t

$\alpha$ : intersep

$\beta_{1}, . ., \beta_{4}$ : koefisien regresi masing-masing variabel bebas subsektor i periode ke-t

$u_{i t}:$ error term

$\mu_{i}$ : efek spesifik individu ke-i

$v_{i t}$ : error antar individu $(1,2, \ldots \ldots, \mathrm{N})$ dan antar waktu $(1,2, \ldots \ldots, \mathrm{T})$

2. Pemilihan model terbaik

Model yang sudah terbentuk antara Common Effects Model(CEM), Fixed Effects Model(FEM), dan Random Effects Model (REM) kemudian dipilih mana yang terbaik. Pemilihan model terbaik dilakukan dengan menggunakan uji Chow dan uji Hausman.

3. Pengujian struktur varians-kovarians residual

Apabila model yang terpilih adalah Fixed Effect Model, maka dilakukan pengujian struktur matriks varians-kovarians residual. Apabila struktur matriks varians-kovarians residual yang dihasilkan bersifat homoskedastik, maka metode estimasi yang digunakan adalah Ordinary Least Square (OLS). Jika struktur matriks varians-kovarians residual yang dihasilkan bersifat heteroskedastik serta terdapat cross sectional correlation, maka metode estimasi yang digunakan adalah Seemingly Unrelated Regression (SUR). Namun jika struktur matriks varians-kovarians residual yang dihasilkan bersifat heteroskedastik dan tidak terdapat cross sectional correlation, maka metode estimasi yang digunakan adalah Weighted Least Square (WLS).

4. Pengujian asumsi klasik pada model yang terpilih

Pemeriksaan asumsi dilakukan menurut metode estimasi yang digunakan. Jika metode estimasi yang digunakan OLS maka dilakukan pengujian seluruh asumsi klasik, yaitu normalitas, nonmultikolinearitas, nonautokolinearitas, dan homoskedastisitas. Kemudian jika metode estimasi yang digunakan SUR atau WLS maka pemeriksaan asumsi yang digunakan adalah normalitas dan nonmultikolinieritas.

5. Pengujian signifikansi estimator koefisien dan evaluasi model regresi

Pengujian signifikansi estimator koefisien model regresi dilakukan dengan menggunakan uji $\mathrm{F}$ dan uji t. Sedangkan evaluasi model regresi dilakukan menggunakan nilai adjusted $R 2$.

6. Interpretasi model regresi

Interpretasi model regresi dilakukan untuk menjawab tujuan penelitian serta mendapatkan kesimpulan dari hasil penelitian.

\section{HASIL DAN PEMBAHASAN}

\section{Gambaran Daya Saing Sektor Manufaktur Unggulan Indonesia}

Perkembangan nilai RCA sektor manufaktur unggulan program Making Indonesia 4.0 dapat dilihat pada Gambar 1. Dari kelima sektor maufaktur unggulan program Making Indonesia 4.0 tidak seluruhnya memiliki daya saing. Hanya industri makanan dan minuman serta industri tekstil dan pakaian jadi yang memiliki nilai RCA di atas satu, yang berarti memiliki daya saing. Sedangkan industri kimia, industri elektronik, dan industri otomotif memiliki nilai RCA di bawah satu, yang berarti tidak memiliki daya saing. Perkembangan nilai RCA dari tahun 2000 sampai dengan 2015 berbeda 
antar sektor manufaktur unggulan. Pada daya saing industri makanan dan minuman terjadi fluktuasi dan memiliki tren yang cenderung positif. Terjadi peningkatan nilai RCA dari awalnya tahun 2000 hingga 2015, pada tahun 2000 nilai RCA industri makanan dan minuman sebesar 1,22 kemudian pada tahun 2015 mencapai 2,88. Pada tahun 2000 sampai 2008 terjadi peningkatan nilai RCA industri makanan dan minuman, kemudian terjadi penurunan yang signifikan pada tahun 2009 yang kemungkinan disebabkan oleh krisis global yang sangat berpengaruh pada industri makanan dan minuman sebagai kebutuhan pokok masyarakat. Pada tahun 2010 sampai 2015 mulai terjadi pemulihan kembali.

Sebaliknya pada industri tekstil dan pakaian jadi terjadi tren yang negatif dari tahun 2000 sampai 2015. Pada tahun 2000 nilai RCA industri tekstil dan pakaian jadi mencapai 2,27 kemudian pada akhirnya di tahun 2015 turun menjadi 1,55. Penurunan nilai RCA industri tekstil dan pakaian jadi ini menandakan bahwa industri tekstil dan pakaian jadi semakin kehilangan daya saing untuk dapat menghadapi produk-produk dari luar negeri. Menurut Prasetyo (2015) penurunan daya saing ini diindikasikan terjadi karena beberapa hal, diantaranya karena tingginya biaya energi, rendahnya produktivitas dan kapasitas SDM, infrastruktur pelabuhan yang tidak kondusif dan mahal, biaya penyusutan mesin-mesin pertekstilan yang besar karena sebagian mesin-mesin sudah sangat tua, dan makin mahal dan langkanya bahan baku impor.

Selanjutnya industri kimia memiliki nilai RCA yang cenderung konstan dari tahun 2000 hingga 2015. Kemudian pada industri elektronik memiliki nilai RCA yang cenderung menurun dari tahun 2000 hingga 2015, walaupun sempat meningkat pada tahun 2000 hingga 2002. Penyebab daya saing industri elektronik yang cenderung menurun dinilai karena bahan baku industri elektronik masih sangat bergantung kepada komponen impor. Bahkan produsen elektronik dalam negeri cenderung hanya melakukan proses perakitan saja. Yang terakhir pada industri otomotif terjadi tren yang positif dari tahun 2000 hingga 2015 dimana selalu terjadi peningkatan nilai RCA dari tahun ke tahun. Hal tersebut menunjukkan walaupun saat ini industri otomotif masih belum berdaya saing, namun industri otomotif menunjukkan potensi untuk terus berkembang di masa yang akan datang.

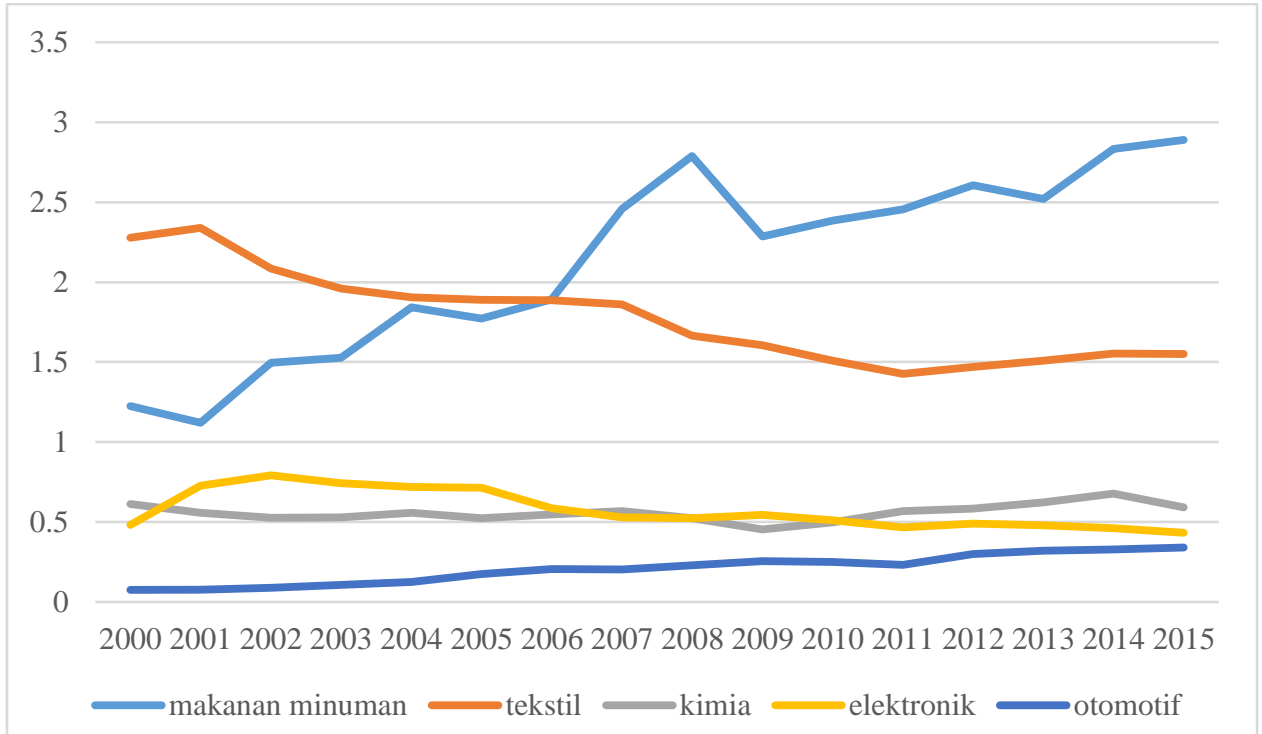

Sumber : World Integrated Trade Solution (diolah)

Gambar 1. Nilai RCA sektor manufaktur unggulan Indonesia tahun 2000-2015

\section{Analisis Daya Saing Sektor Manufaktur Unggulan di ASEAN}

Daya saing sektor manufaktur unggulan Indonesia dibandingkan dengan sektor yang sejenis di negara-negara ASEAN diukur dengan nilai rata-rata RCA sepanjang periode 2000 sampai dengan 2015 digambarkan dalam Gambar 2. Dari kelima sektor unggulan Indonesia tidak semuanya memiliki RCA di atas 1, yang berarti tidak memiliki daya saing. Sektor yang memiliki RCA di atas 1 yaitu industri makanan dan minuman, serta industri tekstil dan pakaian jadi. Sedangkan pada industri 
kimia, elektronik, dan otomotif memiliki RCA di bawah 1. Padahal sebagai sektor yang diunggulkan dalam program Making Indonesia 4.0 seharusnya industri-industri tersebut memiliki daya saing.

Diantara negara-negara di ASEAN terdapat lima negara yang memiliki daya saing di industri makanan dan minuman yaitu Indonesia, Myanmar, Malaysia, Thailand, dan Vietnam. Indonesia sendiri menduduki posisi ke tiga dengan nilai RCA 2,13 kalah dari Vietnam dengan nilai RCA 2,53 dan Malaysia 2,45. Dalam industri tekstil dan pakaian jadi terdapat enam negara yang memiliki daya saing yaitu Indonesia, Kamboja, Laos, Myanmar, Philipina, dan Vietnam. Indonesia berada di posisi ke empat dengan nilai RCA 1,78, tertinggal dari Kamboja di posisi pertama dengan nilai RCA 15,16, kemudian Vietnam 3,69, dan Myanmar 1,96. Nilai RCA Kamboja dalam industri tekstil dan pakaian jadi menjadi paling tinggi kemungkinan disebabkan nilai ekspor dari Kamboja memang didominasi oleh produk dari industri tekstil dan pakaian jadi dibandingkan dengan industri lainnya. Selain itu, sektor yang memiliki daya saing di Kamboja hanya industri tekstil dan pakaian jadi, sedangkan industri lain tidak memiliki daya saing.

Dalam industri kimia negara yang memiliki nilai RCA di atas 1 hanya Singapura, yaitu sebesar 1,21 yang berarti diantara negara-negara ASEAN hanya industri kimia Singapura yang memiliki daya saing sedangkan industri kimia di negara ASEAN lainnya belum memiliki daya saing. Secara peringkat sendiri, Indonesia berada di posisi ke empat dengan nilai RCA 0,55, kalah dari Singapura, Thailand, dan Malaysia. Dalam industri elektronik, terdapat empat negara yang memiliki RCA di atas 1 dari posisi pertama yaitu Philipina, Malaysia, Singapura, dan Thailand. Secara peringkat sendiri, industri elektronik Indonesia berada di posisi ke enam diantara negara ASEAN lainnya. Kemudian dalam industri otomotif, tidak ada satupun dari negara-negara di ASEAN yang memiliki nilai RCA di atas 1. Yang berarti secara rata-rata dari tahun 2000 hingga 2015 tidak ada satupun negara di ASEAN yang memiliki daya saing di industri otomotif.

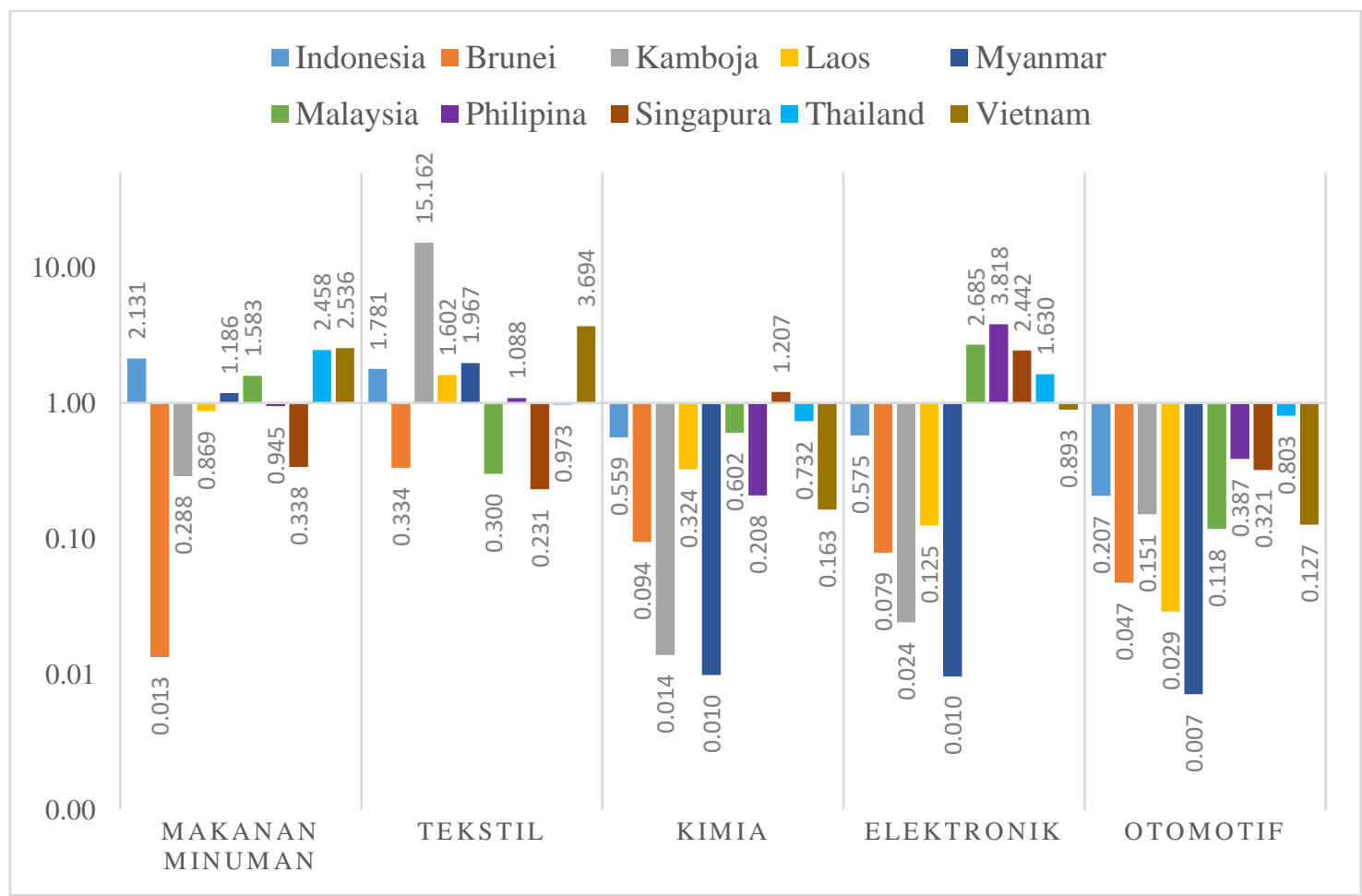

Sumber : World Integrated Trade Solution (diolah)

Gambar 2. Nilai RCA rata-rata sektor manufaktur unggulan di negara-negara ASEAN tahun 20002015 


\section{Variabel-variabel yang Memengaruhi Daya Saing Sektor Manufaktur Unggulan Indonesia}

Analisis regresi data panel digunakan untuk mengetahui pengaruh produktivitas tenaga kerja, Foreign Direct Investment, nilai tukar, dan jumlah perusahaan terhadap daya saing sektor manufaktur unggulan program Making Indonesia 4.0. Setelah membentuk model CEM, FEM, dan REM, maka perlu dipilih model terbaik. Uji Chow dan uji Hausman menunjukkan hasil tolak hipotesis nol sehingga terpilih FEM sebagai model terbaik. Kemudian dilakukan pengujian varians-kovarians residual dengan hasil pengujian menunjukkan bahwa varians-kovarians residual bersifat heteroskedastis dan terdapat cross sectional correlation. Hal tersebut menunjukkan metode estimasi yang digunakan adalah SUR.

Persamaan regresi yang diperoleh dapat ditulis sebagai berikut:

$$
\begin{array}{llll} 
& \widehat{R C A}_{i t}=\left(0,425+\mu_{i}\right) *+0,158 \text { ROD }^{*}{ }_{i t}+0,0378 \text { FDI }^{*}{ }_{i t}-0,015 \text { KURS }^{*}{ }_{t}+0,00028 P^{*}{ }_{i t} \\
\mathrm{R}^{2} & : 0,936093 & \text { F-statistik } & : 129,9996 \\
\text { Adj. } \mathrm{R}^{2} & : 0,928893 & \text { Prob(F-statistik) } & : 0,0000
\end{array}
$$

Keterangan:

*) : : signifikan pada taraf uji 5 persen

Selanjutnya pada model FEM dengan SUR dilakukan pengujian asumsi normalitas dan nonmultikolinieritas. Hasil pengujian normalitas menunjukkan nilai statistik uji Jarque-Berra sebesar 2,828 dengan $p$-value sebesar 0,243 . Nilai $p$-value lebih besar dibandingkan taraf uji 0,05 sehingga keputusan gagal tolak hipotesis nol atau dapat dikatakan residual berdistribusi normal. Pengujian multikolinieritas menunjukkan nilai VIF dari masing-masing variabel bebas tidak ada yang bernilai lebih dari 10. Hal ini menunjukkan bahwa tidak terjadi masalah multikolinieritas dalam model.

Pada uji simultan, nilai statistik uji F diperoleh sebesar 129,999 dengan $p$-value 0,000. Nilai $p$-value lebih kecil dari taraf uji 0,05 sehingga keputusan yang diambil adalah tolak hipotesis nol. Hal ini dapat dikatakan bahwa dengan tingkat signifikansi 5 persen, minimal terdapat satu variabel bebas yang berpengaruh terhadap daya saing sektor manufaktur unggulan program Making Indonesia 4.0. Kemudian dari hasil estimasi model regresi tersebut diperoleh nilai adjusted R2 sebesar 0,9288 . Hal ini berarti secara keseluruhan variabel bebas mampu menjelaskan variasi daya saing sektor manufaktur unggulan program Making Indonesia 4.0 sebesar 92,88 persen dan sisanya yaitu sebesar 7,12 persen dijelaskan oleh variabel lain di luar model.

Selanjutnya pada uji parsial (uji t) setiap variabel bebas terhadap variabel terikat. Berdasarkan hasil output pengolahan, diperoleh hasil nilai $p$-value dari semua variabel bebas lebih kecil daripada taraf uji 0,05. Artinya, dengan tingkat signifikansi 5 persen setiap variabel bebas yaitu produktivitas tenaga kerja, FDI, nilai tukar, dan jumlah perusahaan secara parsial berpengaruh signifikan terhadap daya saing sektor manufaktur unggulan program Making Indonesia 4.0.

Terdapat efek individu yang dapat ditangkap oleh intersep dari Fixed Effect Mode/ dan dapat diinterpretasikan. Berdasarkan nilai intersep untuk setiap sektor manufaktur unggulan, dapat diketahui perbedaan tingkat daya saing antara satu industri dengan industri lainnya. Adapun urutan sektor manufaktur unggulan mulai dari yang memiliki nilai daya saing tinggi adalah: (1) Industri makanan dan minuman, (2) Industri tekstil dan pakaian jadi, (3) Industri elektronik, (4) Industri kimia, (5) Industri otomotif dengan asumsi variabel bebas bernilai sama untuk seluruh sektor. Peringkat dari daya saing sektor manufaktur unggulan berdasarkan intersep tersebut sesuai dengan hasil dari analisis RCA.

Pada variabel produktivitas tenaga kerja terdapat pengaruh signifikan terhadap daya saing sektor manufaktur unggulan Indonesia. Hal ini dibuktikan dengan nilai $p$-value sebesar 0,0002. Produktivitas tenaga kerja memiliki pengaruh positif dengan nilai koefisien regresi variabel sebesar 
0,158. Hal ini berarti bahwa setiap kenaikan 1 miliar rupiah produktivitas tenaga kerja akan meningkatkan nilai RCA sebesar 0,158 satuan dengan asumsi variabel lainnya konstan. Seperti diketahui bahwa suatu perusahaan akan menghasilkan output yang lebih banyak dengan mempekerjakan tenaga kerja dengan produktivitas yang lebih tinggi. Pada akhirnya, peningkatan produktivitas tenaga kerja ini akan berimbas pada peningkatan daya saingnya. Hal ini sesuai dengan teori Porter tentang faktor produksi yang meningkatkan daya saing, serta sesuai penelitian sebelumnya oleh Isventina (2015) dan Bulduk (2011).

Selanjutnya, dapat dilihat bahwa FDI berpengaruh signifikan terhadap daya saing sektor manufaktur unggulan Indonesia. FDI memiliki pengaruh positif dengan nilai koefisien regresi variabel sebesar 0,037879. Yang berarti bahwa setiap kenaikan 1 miliar dollar FDI akan meningkatkan nilai RCA sebesar 0,037879 satuan dengan asumsi variabel lainnya konstan. Hal ini sesuai dengan teori yang menyebutkan bahwa untuk meningkatkan daya saing diperlukan adanya faktor modal. Dengan adanya FDI yang tinggi maka akan memberikan beberapa keuntungan untuk industri di Indonesia seperti memperkenalkan teknologi baru berupa produk, proses, maupun strategi dalam menjalankan usaha. Namun di Indonesia sendiri proporsi nilai FDI terhadap biaya input masih sangat kecil terutama pada kelima sektor manufaktur unggulan yang secara rata-rata kurang dari 10 persen biaya input. Sehingga perlu dilakukan peningkatan FDI lebih tinggi lagi.

Variabel nilai tukar terlihat memiliki pengaruh signifikan terhadap daya saing sektor manufaktur unggulan Indonesia. Nilai tukar memiliki pengaruh negatif dengan nilai koefisien regresi variabel sebesar 0,015. Yang berarti bahwa setiap penurunan nilai tukar nominal (apresiasi) sebesar 1000 rupiah akan meningkatkan nilai RCA sebesar 0,015 satuan dengan asumsi variabel lainnya konstan. Nilai tukar yang kuat dapat memengaruhi secara langsung terhadap fundamental ekonomi suatu negara berkaitan dengan harga-harga komoditas dari jalur impor. Pada industri sektor manufaktur unggulan, sebagian besar inputnya merupakan komponen impor. Kenaikan nilai tukar (depresiasi) dapat menyebabkan peningkatan beban ongkos atau biaya produksi. Sehingga sektor manufaktur sangat rentan terhadap fluktuasi nilai tukar rupiah. Semakin tinggi nilai rupiah terhadap dollar (depresiasi) yang pada awalnya dapat meningkatkan nilai ekspor Indonesia. Namun, karena biaya input yang sebagian besar berasal dari komponen impor, nilai tukar rupiah yang terapresiasi akan meningkatkan produksi sehingga mendorong ekspor yang pada gilirannya dapat meningkatkan daya saing.

Kemudian, variabel jumlah perusahaan diketahui berpengaruh signifikan terhadap daya saing sektor manufaktur unggulan Indonesia. Hal tersebut didukung dengan nilai probabilitas sebesar 0,0000 yang nilainya lebih kecil dibandindkan taraf uji 5 persen. Jumlah perusahaan memiliki pengaruh positif terhadap daya saing sektor manufaktur unggulan dengan nilai koefisien regresi sebesar 0,00028. Hal ini berarti bahwa setiap kenaikan 1000 perusahaan akan meningkatkan nilai RCA sebesar 0,28 satuan dengan asumsi variabel lainnya konstan. Hal ini sesuai dengan hipotesis penelitian bahwa jumlah perusahaan berpengaruh positif terhadap daya saing industri. Hal ini juga sesuai dengan teori modern Hecker-Ohlin yang menyebutkan bahwa daya saing dipengaruhi adanya faktor-faktor endowment yang tinggi diantaranya adalah faktor tanah, yang dapat dijelaskan juga oleh jumlah perusahaan itu sendiri. Kemudian sesuai dengan teori Porter tentang daya saing suatu negara semakin tinggi tingkat persaingan antar perusahaan di suatu negara, maka semakin tinggi pula tingkat daya saing internasionalnya, dengan jumlah perusahaan yang lebih banyak maka akan tercipta persaingan yang lebih tinggi antarperusahaan

\section{KESIMPULAN}

Berdasarkan hasil dan pembahasan, analisis daya saing menggunakan RCA menunjukkan bahwa tidak semua sektor dari lima sektor unggulan manufaktur program Making Indonesia 4.0 memiliki daya saing pada tahun 2000 sampai 2015. Hanya industri makanan dan minuman serta industri tekstil dan pakaian jadi yang memiliki daya saing, sedangkan industri kimia, industri elektronik, dan industri otomotif tidak memiliki daya saing. Daya saing kelima sektor manufaktur unggulan Indonesia 
di ASEAN masih kalah dari negara-negara tetangganya. Industri makanan dan minuman berada di posisi ketiga di bawah Vietnam dan Malaysia. Industri tekstil dan pakaian jadi berada di posisi keempat di bawah Kamboja, Vietnam, dan Myanmar. Industri kimia berada di posisi ke empat di bawah Singapura, Thailand, dan Malaysia. Kemudian industri elektronik menempati posisi ke enam. Industri otomotif tidak ada satupun dari negara di ASEAN yang memiliki daya saing, dan Indonesia menempati posisi ke empat. Kemudian variabel-variabel yang signifikan mempengaruhi daya saing sektor manufaktur unggulan program Making Indonesia 4.0 adalah produktivitas tenaga kerja, Foreign Direct Investment, nilai tukar, dan jumlah perusahaan. Produktivitas tenaga kerja, FDI, dan jumlah perusahaan berpengaruh positif terhadap daya saing sektor manufaktur unggulan, sedangkan nilai tukar rupiah berpengaruh negatif terhadap daya saing sektor manufaktur unggulan.

\section{DAFTAR PUSTAKA}

Baltagi, B. H. (2005). Econometric Analysis of Panel Data. (3rd ed). New York: John Wiley \& Sons Ins

Bulduk, Burak \& Nensi, S. (2011). Determinants of Comparative Advantage in the ICT Goods Market: A CrossCountry Analysis. Jonkoping: Jonkoping University Swedia.

Ekananda, Mahyus. (2016). Analisis Ekonometrika Data Panel Edisi 2. Jakarta: Mitra Wacana Media.

Isventina. (2015). Analisis Daya Saing Sektor Industri Prioritas Indonesia Dalam Menghadapi Pasar ASEAN. Jurnal Ekonomi dan Kebijakan Pembangunan, Vol. 4 No.1, hlm 71-93.

Kementerian Perindustrian. (2018). Making Indonesia 4.0. Jakarta: Kementerian Perindustrian.

Karlinda, Fitri. (2012). Analisis Daya Saing dan Faktor-Faktor yang Memengaruhi Permintaan Ekspor Mutiara Indonesia [Skripsi]. Bogor: Institut Pertanian Bogor.

Porter, M.E. 1990. The Competitive Advantage of Nations. The Free Press: New York.

Raimanu, Gustiawan. (2016). Analisis Daya Saing Indonesia Tahun 2016-2017 Sebuah Analisis Kebijakan Manajemen Keuangan Internasional. Palu : Universitas Tadulako.

Tambunan, Tulus. 2001. Perdagangan Internasional. Jakarta: PT. Pustaka LP3ES Indonesia. 2003. Industrialisasi di Negara Sedang Berkembang, Kasus Indonesia. Jakarta: Erlangga. 